\title{
田中容子（東京都三鷹市立南浦小学校 韸聴学級）
}

1.はじめに

睢聴学級とは、聴覚に障害のある児童・生徒の教育を行うために、通常の小・中学校に 併設されている学級である。学极運営の形態は、各都道府具・各学釉によって異なり、児 童・生徒が通常の学极、及び難聴学級で教育を受ける時間の割合も各学級・個々のケース によってさまざたでる。児童、生徒の中には幼児期にろう学校や医療・福祉機関で早期 訓練を受けた者や、就学前後に障害が発見され、専門機関と連搭を取りながら指導を進め ている者なとがいる。さらに㭪聴器フィッティングゃ聴覚の管理なと、学校教育の中では 医療・福祉との関連の深い部門である。今回、東京都の小学校・難聴学級に通級する児童 の実㿟と、難聴学級の指導について調査を行ったので報告する。

\section{2 . 対象と方法}

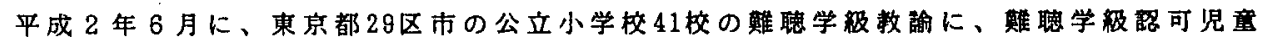
(第1学年から6 学年)に関するアンケート調査を実施した。そのうち40校、261名の児 童について回答を得た。回収夷は $97 \%$ であった。

調査内容は、呪童については学年、性别、聴カレベル、障害の発見時期、就学前教育、

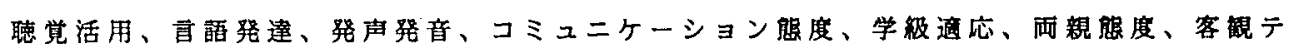
ストの結果であり、指導については個々の児童に対する指導形喼、指道時間、指莩内容、 及び両親指莩や在籍通常学級担任との連携等である。

3 . 結果と考察

(1)児童の学年別の聴カレベルを表 1 に示す。東京都では、難聴学般発足当初の昭和 37 年 には、全蜼聴児のうち平均聴力損失が $60 \mathrm{~dB}$ 以下の児童が $68 \%$ であり、71dB以上の児童は 16 \%であった（谷俊治・難聴教育の現状と問題点一ろう教育モノグラフ・1964）。しかし、

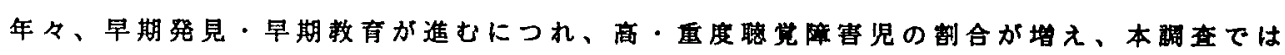
平均聴カレベルが $80 \mathrm{~dB}$ 以上の児童は全体の $45 \%$ 、100dBを超える児童は16\%となっている。 (2)障害の発見は、障客が重いほと早い。聴カレベルが $80 \mathrm{~dB}$ 以上の児勇については $54.5 \%$

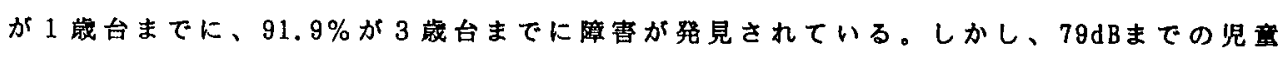
では 1 䠞台までに発見されるものはわずかに $15 \% 、 3$ 留台まででも $45 \%$ であり、就学後に 発見されるケースも多い。（表 2 )

(3)児童の聴カレベルと聴觉活用の状態には明らかな相関が見られた。しかし、80〜 99dB の児童については、聴覚のみで日常会話の内容をかなり聴き取れる者から、ON-0FF程度し かわからない者まで、聴覚活用の程度にバラっきが見られた。また、これらの児童は、コ ミュニケーション場面における自語理解の水準や、学力にもバラつきがあった。聴カレベ ルとコミュニケーション場面における亩語理解の水薄には関連があったが、学力とは無関 係であった。

(4) 3 紫以前に発見されたケースの中で、就学前教育を医療・福祉機関で受けた者は、コ ミュニケーション場面における更祫理解の水準が、ろう学校幼稚部出身者よりやや高い傾 向があった。聴賞活用や言語理解の水準が高いほど、コミュニケーション態度や友人関係 
が良好であった。

(5)学力と聴カレベルの関連はなく、官語性IQとの相関が高かった。

（6）1対 1、または集団におけるコミュニケーション態度と両親の聴覚障害児に対する態 度との関連性は高かった。

（7）難聴学級の指導時間は、週1〜2時間が $54.6 \% 、 3 \sim 4$ 時間が $34 \% 、 5$ 時間以上が $10 \%$ で

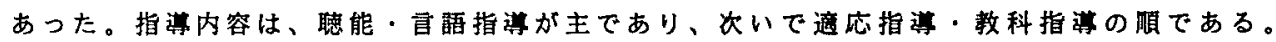
これは、東京都が全国でも例外的に通常の学級からの通級制というシステムを取っており、

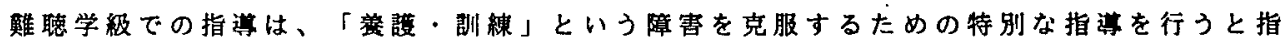

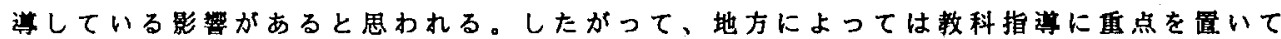
いる学級もあるだろう。

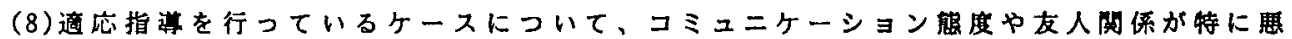
いといろ傾向はなかった。

4.まとめ

(1)聴覚障害の程度が重い児童ほど、早期に発見され、教育されており、これらは聴覚の 活用やコミュニケーション場面における言賭理解に困難があるが、学力的には良い成棈を 上けているものがいた。このことから、高度及び重度聴賞障害児の学力をさらに高めつつ、 聴賞活用、及び官語理解・表現なとの教育プログラムをエ夫が必要であると思われる。

(2)轱・中等度の児童は発見が遈く、日常場面での聴賞活用、言就理解には不自由はしな いが、学力的に問題がないとは言えなかった。これらの児童は一見、日常生活に通応して いるように見受けられるために発見されにくいが、学力に問題があると学校生活への過応 に支障をきたすだけでなく、さまさまな問題が生しるので（王生美智子ら・発見の遅れた 䧾聴児について・日本聴覚医学会·1989）、早期発見、早期救育に努めなけれほならない。 （3）80〜99dBの児童は、聴堂活用、発音・発声、日常のコミュニケーション场面での百語 理解等の、すべての能力にバラつきが見られた。これらの児意は、比的早期に発見され ているので、教育方法の㛟即が望まれる。

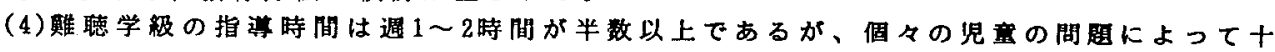
分であるかとうか、两親、在籍学級担任と連搭しながら検即していく必要がある。

表 1 聴力レベル別人数

\begin{tabular}{|c|c|c|c|c|c|c||c|}
\hline$d B$ 学年 & 1 & 2 & 3 & 4 & 5 & 6 & 計 \\
\hline$\sim 39 \mathrm{~dB}$ & 1 & 11 & 6 & 5 & 4 & 4 & 31 \\
\hline $40 \sim 59 \mathrm{~dB}$ & 5 & 12 & 9 & 15 & 8 & 9 & 58 \\
\hline $60 \sim 79 \mathrm{~dB}$ & 8 & 8 & 18 & 9 & 12 & 6 & 61 \\
\hline $80 \sim 99 \mathrm{~dB}$ & 10 & 7 & 11 & 15 & 15 & 14 & 72 \\
\hline $100 \sim 119 \mathrm{~dB}$ & 3 & 6 & 4 & 5 & 5 & 7 & 30 \\
\hline $120 \mathrm{~dB} \sim$ & 1 & 0 & 0 & 0 & 2 & 1 & 4 \\
\hline \hline 計 (人) & 28 & 44 & 48 & 49 & 46 & 41 & 256 \\
\hline
\end{tabular}

表 2 障害の発見年路

\begin{tabular}{|c|c|c|c|c|c|}
\hline $\mathrm{dB}$ 年龄 & $0 \sim 1$ & $2 \sim 3$ & $4 \sim 5$ & $6 \sim$ & 不明 \\
\hline$\sim 39 \mathrm{~dB}$ & 2 & 5 & 7 & 10 & 1 \\
\hline $40 \sim 59 \mathrm{~dB}$ & 10 & 13 & 21 & 11 & 3 \\
\hline $60 \sim 79 \mathrm{~dB}$ & 11 & 25 & 17 & 6 & 2 \\
\hline $80 \sim 99 \mathrm{~dB}$ & 34 & 27 & 3 & 1 & 6 \\
\hline $100 \sim 119 \mathrm{~dB}$ & 18 & 8 & 2 & 1 & 1 \\
\hline $120 \mathrm{~dB} \sim$ & 2 & 2 & 0 & 0 & 0 \\
\hline 部 (人) & 77 & 80 & 50 & 36 & 13 \\
\hline
\end{tabular}

